\title{
Flood Hazard Analysis as Impact of Climate Change on Slum Areas in Palembang, South Sumatera
}

\author{
Anaheryana $^{1}$, Dwi Setyawan ${ }^{1}$, Budhi Setiawan ${ }^{1} \&$ Dadang Hikmah Purnama ${ }^{1}$ \\ ${ }^{1}$ Post Graduate Program of Environmental Science, Sriwijaya University, South Sumatra, Indonesia \\ Correspondence: Anaheryana, Post Graduate Program of Environmental Science, Sriwijaya University, Padang \\ Selasa strait No, 524 Bukit Besar Palembang, South Sumatra, Indonesia. Tel: 62-812-7100-938. E-mail: \\ anaheryana317@yahoo.com
}

Received: December 13, 201x

Accepted: December 24, 201x Online Published: January 29, 2015

doi:10.5539/jsd.v8n1p218

URL: http://dx.doi.org/10.5539/jsd.v8n1p218

\begin{abstract}
Palembang and the surrounding areas there are many slums, especially alongside the river areas, the land is located in the wetlands area in Palembang. The growth of slums Village 5 Ulu Seberang Ulu I district, due to its strategic position in the region where the services and trade, thus becoming the choice of those newcomers to settle into the community and economic life along the river make migrants from villages to bring the crop to trade. From trading there are needs for a place to stay, and they set up lodges in a way ride with landlords and natives Palembang along the river. Eventually from makeshift cottage house, and began to grow houses on stilts. Because it's near the center of trade and services, attracting residents urbanization outside of Palembang to choose to live in this village to find work with do not have the education and special skills, so many emerging slums without complete infrastructure housing is especially sanitation.In Palembang, floodsseems to have a tendency to increase every year. Increasing trend of flooding in Palembang not only the breadth of course, but the loss also increases as well. Materials used in the study was DEM, topographic maps, land use maps, maps tides, river flow data, the coefficient manning, cross section of the river and drainage system data. Value DEM manipulation, spatial patterns of river that flooded as a result of tidal depicted in the map indicates that the area is mostly in the form of alluvial land. Based onthe results ofa GIS analysis of the research region obtained five areas of flood hazard that area $11.43 \%$ very high hazard, high hazard $8.71 \%, 5.99 \%$ medium hazard, low hazard 3.59\%, 70.28\% very low hazard, Where almost all areas of research into the danger area is very high, high, low and very low. Looking at the results that have been obtained through a process of spatial data processing almost the whole area along the river included in the criteria of high hazard is due to the use of land in the form of slums, the soil type is alluvial soil, and most drainage network density contrast is less well. Almost the entire District of Seberang Ulu I have a region surrounding the flat category.
\end{abstract}

Keywords: hazard, climate change, slum area

\section{Introduction}

Indonesia has two seasons, dry and rainy seasons. They have the potential to lead to disaster. The dry season causes dryness and the rainy season causes resulted in flooding. Flooding is an eventflowing an area caused by heavy rain and does not have dikes or dams to accommodate the volume of water resulting in water overflowing river. Flooding is defined as an event boundary overflow of water from the river banks of the river as a result of rising river water flow in a relatively short time (Djojosoeharto 1970, in Widiastuti 2002). Flooding may occur for several hours even for days. Some causes of flooding, namely the existence of illegal logging, the sudden change of seasons and the use of land as a settlement on the banks of the river. The flood disaster that occurred in an area to have some negative impact, namely the dissolution of the access road to other areas, flooded farmland and the incidence of some diseases such as diarrhea and skin diseases due to lack of availability of clean water due to flooding. The magnitude of flooding that occurred in an area depends on several factors that cause flooding, namely rainfall, slope, land use, soil infiltration and flow density.

Palembang and the surrounding areas there are many slums, especially alongside the river areas; the land is located in the wetlands area in Palembang. According to the Directorate General of Human Settlements Department of Public Works physical characteristics of the environment slum area seen from the parameters of the population density of more than 100 inhabitants / ha and for slum which is located alongside the river the size of the river 
border line $<50 \mathrm{~m}$ for small rivers and $<100 \mathrm{~m}$ for large rivers or none at all river demarcation line. The growth of slums Village 5 Ulu Seberang Ulu I district, due to its strategic position in the region where the services and trade, thus becoming the choice of those newcomers to settle into the community and economic life along the river make migrants from villages to bring the crop to trade. From trading there are needs for a place to stay, and they set up lodges in a way ride with landlords and natives Palembang along the river. Eventually from makeshift cottage house, and began to grow houses on stilts. Because it's near the center of trade and services, attracting residents urbanization outside of Palembang to choose to live in this village to find work with do not have the education and special skills, so many emerging slums without complete infrastructure housing is especially sanitation.

Sub district of Seberang Ulu I increased human population because of the allure that stimulate humans moved from rural to urban. Actual lands for preservation and conservation area to maintain balance, taken over for housing, factories, industries, and others. The result can be felt in Palembang District of Seberang Ulu I, the quality of inundation and flooding in some areas when this happens only by the heavy rains of one to two hours of torrential rain is equivalent to one night inseventieth's decade. Season changing factor, climate and unstable weather, all of which can increase the risk and impact of disaster vulnerability, one of which was flooded. Palembang District of Seberang Ulu I is low-lying areas that are prone coastal river floods, not least in the areas around the District of Seberang Ulu I where flooding is a natural occurrence that is unpredictable because it comes suddenly with periodicity erratic, except areas that are already subscribed to annual floods.

Utilization of Geographic Information Systems (GIS) is very important, where the lack of GIS applications can be explained; objects present flood-prone areas of the real world that are used in digital form. Danger of flooding is a problem that has become a priority that should be anticipated and addressed; however, it has not achieved the desired results. With the passage area of flood-prone areas will be no early information to determine which areas are vulnerable to flooding, which can be viewed later on flood vulnerability maps. Where is expected by the flood hazard maps, can be evaluated to minimize the occurrence of flooding in areas including flood-prone areas such as surface drainage improvements.

\section{Method}

Materials used in the study was DEM, topographic maps, land use maps, maps tides, river flow data, the coefficient manning, cross section of the river and drainage system data. Value DEM manipulation, spatial patterns of river that flooded as a result of tidal depicted in the map indicates that the area is mostly in the form of alluvial land. In this study data were used including data RBI Indonesia Digital Map scale 1: 25.000 to Shape file format (Source Bakosurtanal), rainfall data (Source BMG), Land Resource Exploration hardcopy map scale 1: 1000.000 (Land Resource Research Centre and Agro-climate, in 2000). In addition of Palembang Map. The tool of urban spatial survey used is a GPS and some props to support these activities. The research method used in this study is a survey research method; the method of research is done by collecting data through in-depth interviews (In depth interview) to people living in the suburbs Musi River in particular the people who live in 5 Ulu Village. Selection of the study area was done by purposive.

In this study, the data were analyzed by using the flow of activities such as data reduction, the data display and conclusion drawing. The data obtained through observation, interviews and documentation so many and complex, and they are mixed, then the reduction made to the data. In this reduction process, it is done by selection to select relevant and meaningful data which leads to problem solving, discovery, purport to answer the question. Furthermore, the data is processed with the help of the program ILWIS 3.6 based Geographic Information System, which determine the level of danger are grouped into five levels, namely the danger of very low, low hazard, medium hazard, high hazard and danger is very high. 


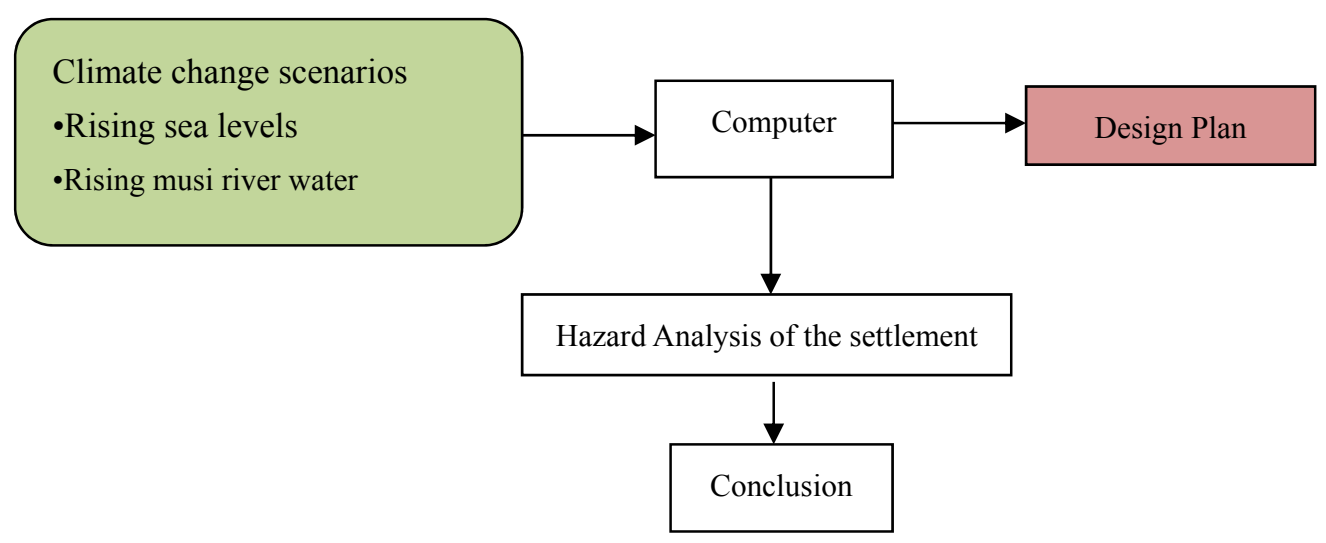

Figure 1. Flowchart flood analysis slum areas

\section{Results}

\subsection{Analysis of Flood Risk Area}

To determinethe maximum high tide water level (HHWL) and high tide water level average (MHWL), the measurement of the Musi River Palembang. Measurements were taken for 3 days to obtain amplitude and constanttidal using TideWX tool version 4.7. Furthermore, it is done by calculation to determine the complete tidal patterns. The research result shows the maximum high tide water level (HHWL) $150 \mathrm{~cm}$ and height of tide water level average (MHWL) is $120 \mathrm{~cm}$.

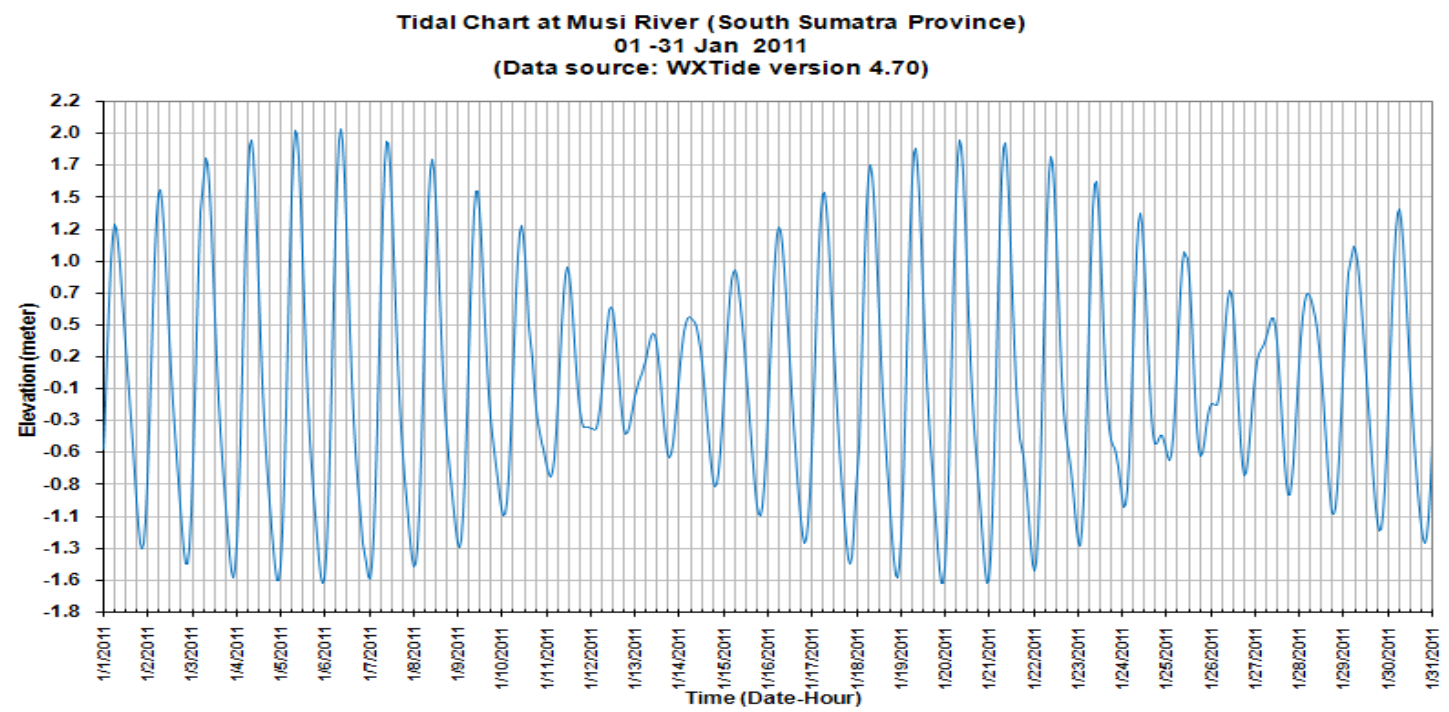

Figure 2. Measurement results tidal Musi River Palembang

From the results of the above studies and oceanographic scientific basis of measurement results tidal danger then drafted a scenario based on the danger element that can be seen in Table 1 and 2 
Table 1. Elements of hazard at sea level

\begin{tabular}{lcccl}
\hline & Hazard & \multicolumn{2}{c}{ SRES A1B Projection } & Frequency \\
\cline { 3 - 4 } Hazard Elemen & Code & $\mathbf{2 0 1 0}$ & $\mathbf{2 0 3 0}$ & \\
\cline { 3 - 4 } & & $\mathbf{( c m )}$ & $\mathbf{( c m )}$ & \\
\hline Average Attach ( MHWL ) & $1 \mathrm{a}$ & 120 & 120 & 115,6 hour/year $(4,6 \%)$ \\
Maximum Attach ( HHWL $)$ & $1 \mathrm{~b}$ & 150 & 150 & 35,4 hour/year $(0,76 \%)$ \\
Maximum Attach $^{1)}$ & $2 \mathrm{a}$ & 31,1 & 31,1 & $\mathrm{~T}=6$ second \\
Significant Wave $^{1)}$ & $2 \mathrm{~b}$ & 38,4 & 38,4 & $\mathrm{~T}=7$ second \\
Sea Level $^{1)}$ & 3 & 0 & $13,5 \pm 6.5$ & Projection \\
La- Nina $^{1)}$ & 3 & 15 & 15 & 1 event $/ 2-3$ years \\
Storm Surge $^{1)}$ & 4 & 20 & 20 & 3 event / year/ 3 days \\
Flooding $^{1)}$ & 5 & 100 & 100 & \\
\hline
\end{tabular}

Description ${ }^{1)}$ Results based studies scientific oceanography KRAPI South Sumatera

Table 2. Scenario hazards due to Sea Level Rise

\begin{tabular}{llcc}
\hline \multicolumn{1}{c}{ Scenario } & \multicolumn{1}{c}{ Cumulative } & \multicolumn{2}{c}{ SRES A1B Projection } \\
\cline { 3 - 4 } & \multicolumn{2}{c}{ 2010 (Cm) } & 2030 (Cm) \\
\hline Scenario 1a ( Existing) & $1 \mathrm{a}+2 \mathrm{a}+3$ & 151,1 & 165 \\
Scenario 1b ( Extreme ) & $1 \mathrm{~b}+2 \mathrm{~b}+3$ & 188,4 & 201,9 \\
Scenario 2a (Extreme + La-Nina ) & $1 \mathrm{~b}+2 \mathrm{~b}+4+3$ & 203,4 & 216,9 \\
Scenario 2b (Extreme + Surge ) & $1 \mathrm{~b}+2 \mathrm{~b}+5+3$ & 208,4 & 221,9 \\
Scenario 3 (Extreme + La-Nina + Surge ) & $1 \mathrm{~b}+2 \mathrm{~b}+4+5+3$ & 228,4 & 241,9 \\
Scenario 4 (Extreme + La-Nina + flood ) & $1 \mathrm{~b}+2 \mathrm{~b}+4+6+3$ & 303,4 & 316,9 \\
\hline
\end{tabular}

From the results of the tidal scenario, inundation hazard maps can be made for the baseline condition in 2010 and projected conditions in 2030, can be seen in Fig. 3 and Fig. 4 


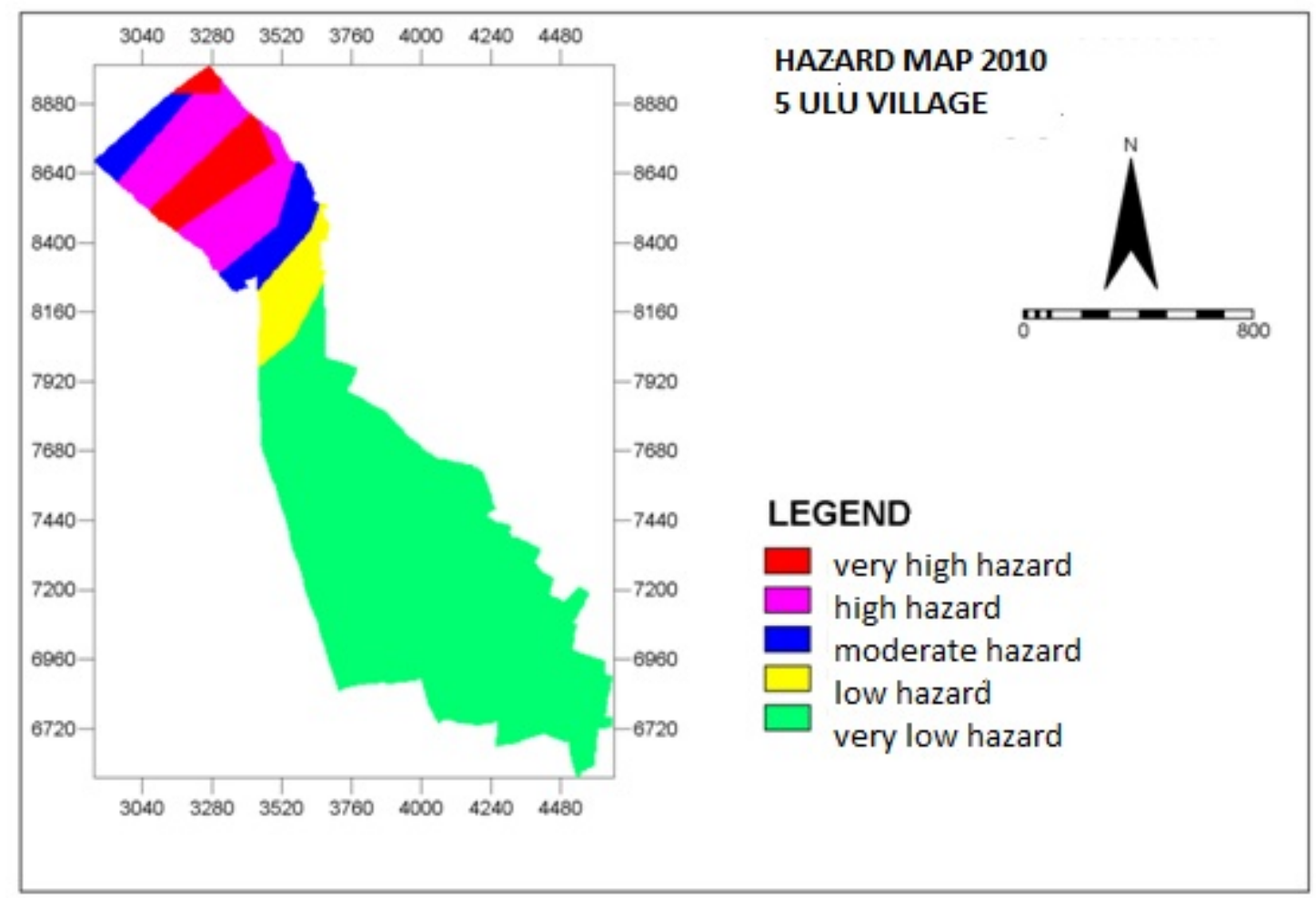

Figure 3. Inundation hazard map 2010 Village 5 Ulu

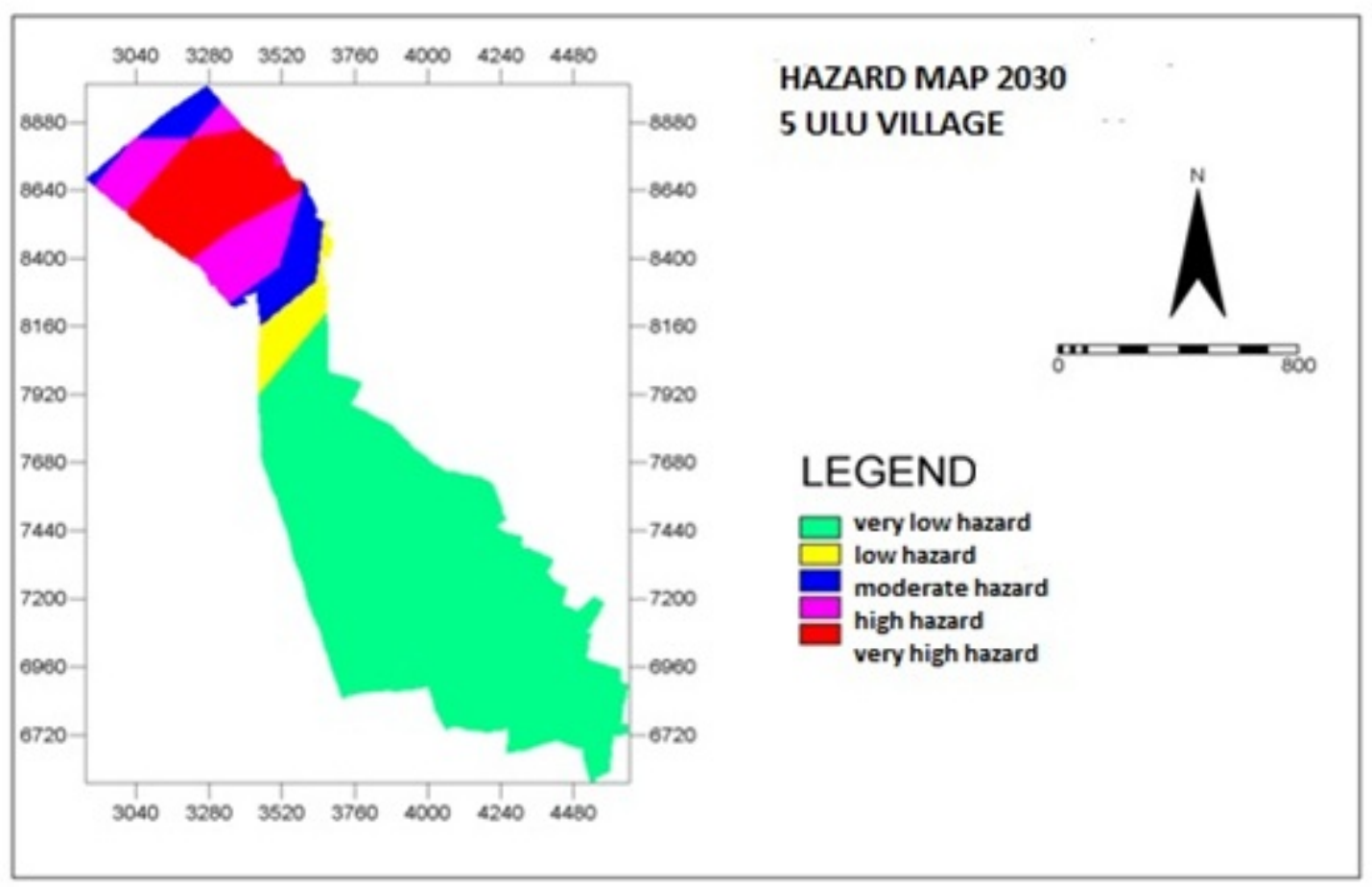

Figure 4. Inundation hazard map 2030 Village 5 Ulu 
Looking at Figure 3 and 4 based on the analysis of the factors that influence hazards in the District Seberang Ulu I, inparticular the Village 5 Ulu who have passed from the descriptive analysis based on field data, GIS analysis, obtained factors that influence the hazard of inundation. Hazard from the economic aspect consists of the percentage of households that work and the percentage of poor households.

Judging from the intensity of rainfall,topography and slope heights Village 5 Ulu Seberang Ulu I Sub district based scenarios hazard due to sea level rise in Table 2. Scenario 3 (La-Nina + extreme + surge) in 2010 SRES projections AIB, 203,4 cm in 2010 reached 241, $9 \mathrm{~cm}$. Based on the results of a GIS analysis of the research region obtained five areas of hazard is very high hazard area 5.28\%, high hazard area $12,11 \%$, the moderate hazard $6.89 \%, 5.12 \%$ low hazard and very low $70.59 \%$. Area where almost all the research into the hazard area is very high, high, moderate, low and very low. From Figure 3 inundation hazard maps of 5 Ulu political district administrated Seberang Ulu I Sub district,in 2010 very high inundation hazards present only in RT 3, 4, 6, 10, and 11, high hazards 02, 03, 04, 05, 06, 07, 08, 09, 10,12, 16, and 17, moderate RT01, 05, 06, 07, 13, 14, 15, and 18, low hazard of RT 19, 21, 24, 27, and32 while the very low hazard RT 25, 26, 28, 29, 30, 31,32, 33, 34, 35,36, $38,39,40,41,42,43,44,45,46,47,48,49,50,51,52,53$, and 54. However, based on field data and GIS analysis in the absence of government policy for the Village 5 Ulu, so in 2030 a pool of very high hazard will extend to RT $1,3,4,5,6,8,10,11,12,16$, and thus the RT 17 year 2030 reached $303,9 \mathrm{~cm}$. Based on the results of a GIS analysis of the research region obtained five areas of that area $11.43 \%$ very high, high hazard $8.71 \%$, $5.99 \%$ moderate hazard, low $3.59 \%, 70.28 \%$ very low hazard, where almost all areas of research into the hazard area is very high, high, moderate, low and very low. Looking at the results that have been obtained through a process of spatial data processing almost the whole area along the river included in the criteria of high hazard is due to the use of land in the form of slums, the soil type is alluvial soil, and most drainage network density contrast is less well. Almost the entire District of Seberang Ulu I have a region surrounding the flat category, it will be possible occurrence of flooding because the area tend to be flat when the rain water storage. Soil types of Seberang Ulu I district generally are alluvial soil types that have a permeability infiltration $<0.5 \mathrm{~cm} /$ his small which makes the longer stagnant water on the surface soil. It could be concluded that the main factor District of flood hazard Seberang Ulu I Village 5 Ulu and the surrounding village is 0-8 \% slope, alluvial soil type sand land uses that do not fit. While the area is included in the hazard criteria being is because the region has a density of better drainage network $>3.10 \mathrm{~km} / \mathrm{km}^{2}$. While the area qualifies as a very low hazard is an area that has a slope $>40 \%$, the type of soil is soil mediterranean, and have the good drainage network density and land use is still a wasteland. This can be seen in the results of the field survey.

\subsection{Adaptation}

For neighborhoods that are too dense to be hard to do repairs village because of the difficulty gaining ground to make environmental infrastructure, in addition to density has not allowed for the creation of a healthy urban environment. Therefore, neighborhoods like the Village 5 Ulu this needs to be organized based on the concept of rejuvenation slums. In order to accommodate the entire population of the original and provide land for various infrastructure and environmental facilities, the new building should be graded so that there will be a simple flat environment. Longer habitant be compensated fairly for payment DP Housing Loan. The city's renovation with improved urban environment, here the power of government / public investment is very dominant, or the single factor of urban development was the construction of flats as solving a seedy neighborhood.

The commitment of local government in this case the City of Palembang assessed as having contributed to the implementation of handling very large slum area. This is an indication that the local government has wanted the regularity of existing regional development, especially in the region. In the slum area of government involvement plan is realized by providing assistance through programs financed from the budget, ADD, and other PNPM. Assistance in the form of infrastructure improvements such as roads, water supply and others as needed and each region, but there are also some areas that have not been touched by the help of the government.

Counseling by the Local Government Local in this case the Village, can perform outreach activities in collaboration with the relevant agencies with materials related to the completion of the practical concept of the main problems faced by migrants, particularly on equity or return of the population, an increase in knowledge and awareness of the law. Efforts in the field slums solution, in a more humane and consider the best way out and side to migrant interests. Solution is not done brutally by displacing without notice and adequate time limits. Treatment and harsh sanctions, such as excessive fines, confiscation of property, or indemnification must be avoided pressing. 


\section{Conclusion}

District of Seberang Ulu I Village 5 ulu is aslum area by weight based on the comparison of the size and number of population and economic life level of the community. Hazard areas were divided into five classes very highhazard area, high hazard, moderate hazard, low hazard and very low hazard. Research area has proportion of the area potentially dangerous floods with very high hazard categories, namely RT 1, 3, 4, 10,11, and RT 12 . Need for physical improvement of drainage with maintenance of existing drainage by dredging waste that impede the flow water, the addition of a drainage channel at a point that has not been available and the provision of integrated drainage system, which facilitates both government funds and goods, while the implementation is done by the community.

\section{References}

Affeltranger, B. et al. (2006). Living With Risk: A Global Review of Disaster Reduction Initiatives, ISDR.

Boer, R. (2011). Ancaman Perubahan Iklim terhadap Ketahanan Pangan.Presentasi pada Workshop Nasional dan FGD Adapatasi Perubahan Iklim. Bandung 9-10 November 2011. Balai Besar Sumberdaya Lahan Pertanian. Kementerian Pertanian.

Brooks, N., Neil Adger, W., \& Mick Kelly, P. (2005). The Determinants of vulnerability and adaptive capacity at national level and the implications for adaptation, Elsevier Ltd.

CSIRO Marine and Atmospheric. (2007). Infrastructure and Climate Change Risk Assessment for Victoria, A Victoria Government Initiative, Australia.

Hansen, J., Sato, M., Ruedy, R., Lo, K., Lea, D. W., \& Medina-Elizade, M. (2006). Global temperature change. PNAS, 103, 14288-14293. http://dx.doi.org/10.1073/pnas.0606291103

IPCC TAR. (2001). Climate Change 2001: Synthesis Report. IPCC-UNEP-WMO.

IPCC. (2007). Climate Change 2007: The Physical Science Basis. Contribution of Working Group I to the Fourth Assessment Report of the Intergovernmental Panel on Climate Change [Solomon, S., D. Qin, M. Manning, Z. Chen, M. Marquis, K.B. Averyt, M.Tignor and H.L. Miller (eds.)]. Cambridge University Press, Cambridge, United Kingdom and New York, NY, USA.

IPCC. (2007). Climate Change 2007: The Physical Science Basis. Summary for Policymakers. Intergovernmental Panel on Climate Change, Geneva.

Klein, R. J. T. (1997). Mainstreaming Climate Adaptationinto Development A Policy Dilemma. Climate Governance and Development InternationaleWeiterbildung und Entwicklungg GmbH - Capacity Building International Germany The World Bank Washington D.C.

Naylor, R. L., Battisti, D. S., Vimont, D. J., Falcon, W. P., \& Burke, M. B. (2007). Assessing the risks of climate variability and climate change for Indonesian rice agriculture. Proc. Nat. Acad. Sci., 104, 7752-7757. http://dx.doi.org/10.1073/pnas.0701825104

Nova Fitria Resiwiyasa. (2014). Analisis Perubahan Penggunaan Lahan untuk Pemukiman di Kecamatan SeberangUlu I Kota Palembang Propinsi Sumatera Selatan 2004-2012.

Peterson, L., \& Haug, G. (2005). Climate and the Collapse of Maya Civilization : Aseries of multi-year droughts helped to doom an ancient culture, Sigma Xi, The Scientific Research Society

Ratag, M. A. (2001). Model Iklim Global dan Area Terbatas serta Aplikasinya di Indonesia.Paper disampaikan pada Seminar Sehari Peningkatan Kesiapan Indonesia dalam Implementasi Kebijakan Perubahan Iklim. Bogor, 1 November 2001.

Rygel, L., O’sullivan, D., \& Yarnal, B. (2006). A Method for Constructing a Social Vulnerability Index: An Application to Hurricane Storm Surges in a Developed Country, Mitigation and Adaptation Strategies for Global Change (2006) 11: 741-764, Springer Ltd. http://dx.doi.org/10.1007/s11027-006-0265-6

Setiawan, B., Puspita, N., \& Setiojati, A. (2010). Vulnerability Assessment of Urban Infrastructure: A Framework and Conceptual Model, Proceeding Seminar Nasional Teknik Sipil VI - 2010. VolII : p-C61-C70.

Smit, B., \& Pilifosova, O. (1993). Adaptation to Climate Change in the Context of Sustainable Development and Equity. Chapter 18 in Climate Change 2001: Impacts, Adaptation, and Vulnerability - Contribution of Working Group II to the Third Assessment Report of the Intergovernmental Panel on Climate Change. Cambridge University Press, Cambridge, UK.

Suroso, D., Wahyudi, T., Sofian, I., Latief, H., Abdurahman, O., \& Setiawan. B. (2009). Vulnerability of Small 
Islands to Climate Change in Indonesia : a case study of Lombok Island, Province of Nusa Tenggara Barat, Proceeding WOC Conference: Water and Coastal Sector, Manado.

Timmerman, A., Oberhuber, J., Bacher, A., Esch, M., Latif, M., \& Roeckner, E. (1999). Increased El Niño frequency in a climate model forced by future greenhouse warming. Nature 398.

Yusuf, Arief A., \& Francisco, H. (2009). Climate Change Vulnerability Mapping for Southeast Asia. Economy and Environment Program for Southeast Asia.

\section{Copyrights}

Copyright for this article is retained by the author(s), with first publication rights granted to the journal.

This is an open-access article distributed under the terms and conditions of the Creative Commons Attribution license (http://creativecommons.org/licenses/by/3.0/). 